Artículos

ESTUDIOS SOCIALES

\title{
Socialistas, anarquistas, católicos y liberales: trabajadores y política en la Buenos Aires del
} novecientos

\section{Socialists, Anarchists, Catholics and Liberals: workers and politics in turn-of-the-century Buenos Aires}

Hora, Roy

Roy Horarhora@unq.edu.ar Universidad Nacional de Quilmes - Consejo Nacional de Investigaciones Científicas y Técnicas, Argentina

Estudios Sociales. Revista Universitaria Semestral Universidad Nacional del Litoral, Argentina

ISSN: 0327-4934

ISSN-e: $2250-6950$

Periodicidad: Semestral

núm. 61, e0001, 2021

estudiossociales@unl.edu.ar

Recepción: 18 Agosto 2020

Aprobación: 01 Marzo 2021

URL: http://portal.amelica.org/ameli/jatsRepo/293/2932743001/ index.html

DOI: https://doi.org/10.14409/es.2021.2.e0001

El contenido está bajo Licencia Creative Commons AtribuciónNoComercial-Compartir Igual 4.0 Internacional. Atribución - No Comercial - Compartir Igual (BY-NC-SA): no se permite un uso comercial de la obra original ni de las posibles obras derivadas, la distribución de las cuales se debe hacer con una licencia igual a la que regula la obra original.

\section{(7) (2)}

Esta obra está bajo una Licencia Creative Commons AtribuciónCompartirIgual 4.0 Internacional.
Resumen: Los estudios sobre la relación entre mundo del trabajo y política en la era oligárquica suelen enfocarse en las iniciativas políticas y gremiales de socialistas y anarquistas. Con el fin de ofrecer un panorama más completo de la experiencia política popular para la Buenos Aires del novecientos, este artículo desplaza la atención hacia otros actores. Sugiere que católicos, liberales y empresarios también deben ser tenidos en cuenta al momento de reconstruir el escenario en el que se desplegó la experiencia política de los trabajadores. Finalmente, también formula algunas consideraciones sobre los vínculos entre el Estado y las organizaciones gremiales y políticas de izquierda, muchas veces desatendidos, que nos permiten encuadrar mejor el problema del lugar de los trabajadores en la sociedad argentina del novecientos.

Palabras clave: trabajadores, política, Buenos Aires, historia, izquierda.

Abstract: Studies on the relationship between labour and politics in Argentina during the oligarchic regime tend to focus on the political initiatives of Socialists and Anarchists militants. In order to present a more complete picture of the political experience of Buenos Aires's working classes, this article draws attention to Catholics, Liberals and factory owners - whose importance has been largely neglected in historical accounts of the world of labour in this period. Finally, it also looks at the links between unions and left wing activists and the State.

Keywords: workers, politics, Buenos Aires, history, left.

\section{Introducción}

En los estudios sobre la historia de los trabajadores argentinos, los años del paso del siglo XIX al XX suelen describirse como una etapa de incremento de la influencia anarquista y socialista entre las clases subalternas y de fortalecimiento de la organización sindical. Se ha sugerido muchas veces que el proceso de formación de clase que subtendía este ascenso proletario comenzó a bosquejarse en la década de 1870, cuando aparecieron las primeras asociaciones 
obreras, organizadas casi todas ellas por inmigrantes europeos. Estos pequeños círculos de militantes de izquierda surgidos primero en Buenos Aires y luego en otras ciudades litorales como Rosario, continúa el argumento, fueron acrecentando su importancia en los últimos dos decenios del siglo, conforme más y más trabajadores sintieron la presión de la explotación capitalista y de un orden político excluyente. La Crisis del Noventa, que trajo desempleo y emigración, interrumpió el ascenso de la política de clase. Pero una vez que la economía retomó su ritmo expansivo, profundizando las formas capitalistas de organización de la producción, el ambiente se tornó muy propicio para la formulación de demandas obreras y la difusión de la prédica clasista.

De acuerdo a esta visión, este avance proletario tuvo su epicentro en las grandes ciudades y los puertos litorales. La campaña pampeana, lo mismo que el interior del país, se mantuvieron mayormente refractarios al despliegue de la política de clase, que adquirió un tono inconfundiblemente urbano. A mediados de la década de 1890 nació en la ciudad de Buenos Aires el Partido Socialista, donde confluyeron organizaciones gremiales y grupos políticos de inspiración socialdemócrata. En esos mismos años, el anarquismo, una propuesta aún más radical, también incrementó su ascendiente popular, y pasó a convertirse en la fuerza más dinámica del movimiento obrero. El creciente influjo de estas propuestas de izquierda se puso de relieve en el ciclo de protesta que culminó en noviembre de 1902 con una huelga general que paralizó a las principales ciudades del país, y a la que la elite gobernante respondió redoblando su sesgo antiobrero: ya no sólo reprimiendo a los trabajadores sino también imponiendo el Estado de sitio y sancionando una ley de expulsión de extranjeros. De acuerdo a estos relatos, pues, el cambio de siglo constituye un momento crucial en la historia política popular. En esos años se reveló a la luz del día la maduración de una clase obrera contestataria que, inspirada por ideales socialistas y anarquistas, y en abierto desafío a un orden excluyente, ya podía caminar sobre sus propios pies ${ }^{[1]}$.

Pese a que esta narrativa posee un considerable influjo historiográfico, sólo capta aspectos parciales de la historia política de las clases trabajadoras de fines del siglo XIX. Su principal limitación radica en que concentra demasiada atención en los círculos de izquierda del asociacionismo obrero y, en consecuencia, tiende a proyectar sobre el mundo del trabajo en su conjunto el espíritu de impugnación que, en rigor, sólo predominaba entre algunos de sus segmentos minoritarios. Además de sobrestimar el influjo de los críticos del orden sociopolítico tanto entre los activistas como entre las y los trabajadores del común, esta visión suele tomar por válido el argumento de que libertarios y socialdemócratas eran los únicos actores que tenían la ambición de interpelar y movilizar a las clases subalternas y, por sobre todas las cosas, los únicos que contaban con la vocación política y la legitimidad histórica para hacerlo.

Al calor de la renovación interpretativa que la historia política ha experimentado en las últimas décadas, algunos estudios recientes sobre el mundo del trabajo comienzan a incorporar la idea de que el orden político de la era de Roca descansaba sobre un cierto grado de participación popular. El panorama abierto por los estudios sobre la cultura de la movilización, la prensa y los partidos políticos finiseculares muestra que los términos trabajador y vida cívica no deben ser vistos como excluyentes. Con demasiada frecuencia, sin embargo, en los estudios enfocados en el mundo del trabajo la cuestión de la inclusión de las 
clases subalternas en la vida pública tiende a ser encuadrada bajo el término estigmatizante de clientelismo político, es decir, como una manifestación espuria de la voluntad de las mayorías. Y esto es así porque, al margen de estas formas de participación cívica vistas como poco auténticas, cuando no artificiales, la política popular del fin de siglo continúa siendo percibida como un fenómeno signado, en primer lugar, por el rechazo popular al orden sociopolítico existente. La vigencia de este enfoque se advierte al comprobar que, en muchos casos, los estudios que han desplazado el foco de atención hacia nuevas problemáticas -el trabajo femenino e infantil, los emprendimientos culturales de anarquistas y socialistas, la dimensión de género- continúan inscribiendo sus contribuciones en el marco de una narrativa en la que la asociación entre izquierdas, movimiento obrero y política popular desempeña un papel analítico primordial $^{[2]}$. La política obrera y popular continúa siendo imaginada, ante todo, como política antisistema.

Este artículo discute este argumento. Sugiere que una mejor comprensión del lugar de las clases trabajadoras en la vida pública del Buenos Aires finisecular debe partir de la premisa de que socialistas y anarquistas no actuaban en un vacío político. Hay que aclarar que este ensayo concentra su atención en los actores que se proponían movilizar el potencial político de los trabajadores en tanto trabajadores, dejando de lado la cuestión crucial de la relación entre los partidos políticos que actuaban en la ciudad y sus votantes populares. ${ }^{[3]}$ Explora este problema a partir de la premisa de que católicos, liberales y empresarios también deben ser tenidos en cuenta al momento de establecer los parámetros a partir de los cuales se forjó la experiencia política de los asalariados. Además, formula algunas consideraciones sobre las relaciones entre organización gremial e instituciones estatales como la policía y la administración de justicia. Sin considerar a este conjunto de actores, cuyas relaciones con el mundo del trabajo son exploradas de manera sintética en este ensayo, el panorama no sólo no está completo sino que, lo que es peor, aspectos relevantes del orden político finisecular -como su considerable capacidad inclusiva, y el peso del ideario liberal y constitucional- no pueden comprenderse de manera cabal. El autor de estas páginas es consciente de que, al ampliar el campo de indagación para comprender las iniciativas de católicos y empresarios, de liberales y de agentes del orden, este artículo resigna profundidad analítica. Sin embargo, esta opción se justifica por cuanto una exploración más comprensiva de los distintos actores que moldearon la experiencia política popular en esa etapa formativa del movimiento obrero constituye una asignatura pendiente, que nuestra historiografía aún no ha encarado de manera sistemática.

El artículo comienza examinando la gravitación de las organizaciones gremiales anarquistas y socialistas en el mundo del trabajo finisecular, y sostiene que ésta fue más modesta de lo que se sugiere habitualmente. Luego gira la atención hacia otros proyectos que también se propusieron conquistar el apoyo de los asalariados. Se refiere, en particular, a las iniciativas desplegadas por el gremialismo católico y el empresariado. A continuación, explora cómo era vista la organización sindical por las fuerzas del orden, y analiza de qué manera socialistas y libertarios concebían, en la práctica, a las instituciones políticas argentinas. Muestra que no sólo los socialistas sino también los anarquistas entendían que las garantías constitucionales eran centrales para el desarrollo de su programa político. El artículo se cierra con una breve exploración de las disputas 
en el seno del socialismo en torno al dilema que les planteaba el desafío del liberalismo popular. Volver sobre este capítulo borrado de la memoria histórica de la izquierda -a la vez que ignorado por los estudios históricos sobre este sector de la opinión- sirve para constatar que, cuando comenzaba el nuevo siglo, tanto socialistas como libertarios entendían que estaban lejos de encaminarse, de manera inevitable, hacia un choque con el Estado oligárquico. Para ellos, la crisis de noviembre de 1902, que abrió un nuevo capítulo en la historia de la relación entre trabajadores y orden político, no estaba en el horizonte.

\section{Organización gremial, anarquistas y socialistas}

Una comprensión acabada de la historia política de los trabajadores en el cambio de siglo obliga a tomar distancia de la premisa de que en la era oligárquica no habría existido otra política obrera que la de izquierda. En esta línea, lo primero que hay que recordar es que los actores que, inspirados por visiones libertarias o socialdemócratas, pretendían transformar el orden socio-político, sólo encuadraban a una porción muy reducida de los asalariados. En una ciudad como Buenos Aires, que hacia el cambio de siglo contaba con unos 800.000 habitantes y cerca de 300.000 trabajadores varones, de los cuales más de dos tercios eran extranjeros, la endeble Federación Obrera que los anarquistas pusieron en pie en los primeros años del siglo XX -el esfuerzo de coordinación gremial más relevante del período que abordamos en estas páginas- apenas reunía, según los generosos cálculos de sus organizadores, unos 7.500 afilados. Dejando de lado el hecho de que es muy dudoso que todos los trabajadores encuadrados en estas organizaciones tuviesen un apego a la idea libertaria de intensidad equivalente al que predominaba entre sus dirigentes, lo cierto es que se trataba de un porcentaje muy reducido de la fuerza laboral. El total de afiliados a la docena de sociedades gremiales lideradas por anarquistas era muy inferior al número de carpinteros (9.100), o albañiles (11.300), o cocineros (9.500) o zapateros (10.100) que, sólo en la capital de la república, registra el censo de 1895. Por supuesto, las agrupaciones orientadas por figuras próximas al Partido Socialista tenían aún menos porte, y difícilmente reunieran 3.000 afiliados $^{[4]}$.

En el principal polo obrero e industrial de la república, en el distrito donde su presencia era más conspicua, las organizaciones comandadas por libertarios o socialistas encuadraban, a lo sumo, a uno de cada veinte trabajadores. Pero es preciso ir más allá de esta estimación algo tosca y recordar, además, que socialistas y anarquistas nunca actuaron en un vacío político u organizativo. Los esfuerzos de estos críticos del orden establecido para despertar el espíritu asociativo y contestatario de las clases populares convivieron con otras empresas que también gozaban de legitimidad a los ojos de gran cantidad de asalariados. En primer lugar, ácratas y socialistas compartían el ámbito del trabajo sindical con un conjunto de asociaciones gremiales que se mantenían al margen de cualquier forma de adscripción político-ideológica precisa (entre otros cosas, porque su principal objetivo era encuadrar a trabajadores de muy distinto grado de politización y de preferencias ideológicas muy diversas). Abocados a la difícil tarea de construir organizaciones de mayor alcance y solidez, los animadores de estos emprendimientos de ambiciones políticas más circunspectas solían estar imbuidos de una sensibilidad anticapitalista que, a veces, informaba su retórica, 
pero que carecía de verdadera incidencia sobre su práctica sindical. Convencidos de la importancia de dialogar con los empresarios, dispuestos a aceptar e incluso a solicitar la mediación de las autoridades, respetuosos del marco institucional de la república capitalista, sus dirigentes contribuyeron a forjar un gremialismo más inclinado a la negociación que a la impugnación, que desde el comienzo receló de cualquier forma de involucramiento político. Con frecuencia se sugiere que un sindicalismo de este tipo sólo cobró forma hacia 1906, cuando un conjunto de organizaciones gremiales crecidas bajo el ala del Partido Socialista tomó distancia de este partido para dar forma a un gremialismo desprovisto de aspiraciones políticas (el asíllamado sindicalismo revolucionario). Pero esta sensibilidad había nacido mucho antes. En rigor, este tipo de orientación fue, desde el comienzo, la más gravitante del universo gremial argentino.

En la medida en que su trabajo militante estaba concentrado en las laboriosas pero grises tareas de la organización gremial, a que sólo en contadas ocasiones creían conveniente invertir recursos en iniciativas de coordinación con otros gremios y sindicatos, y a que se resistían a articular sus demandas laborales con proyectos políticos más amplios, las alternativas de la vida cotidiana de estas asociaciones $-\mathrm{e}$ incluso muchos de sus logros-, rara vez aparecían en letras de molde en publicaciones como La Vanguardia o La Protesta Humana, los principales voceros de las posiciones socialistas y anarquistas respectivamente, y los medios de prensa privilegiados por quienes se han propuesto reconstruir la vida política y sindical de las clases trabajadoras de esos años ${ }^{[5]}$.

Es lo que se observa, por caso, entre los trabajadores del riel que, a partir de la fundación de La Fraternidad por los maquinistas del Ferrocarril del Oeste en 1887, crearon las organizaciones más poderosas de la era agroexportadora. El hecho de que en marzo de 1889 el presidente Miguel Juárez Celman rubricara con su firma el estatuto de La Fraternidad -lo más parecido a un reconocimiento legal para una sociedad gremial que la Argentina de fin de siglo podía ofrecer- nos da una idea de la relevancia de esta organización y, sobre todo, de su disposición a reconocer la legitimidad de los ocupantes de la Casa Rosada. Pese a que los ferroviarios pusieron en pie el sindicato de mayor envergadura de ese período, y un tiempo después la primera asociación gremial de alcance nacional, los esfuerzos dirigidos a la construcción de su Confederación de Ferrocarrileros están prácticamente ausentes de las páginas de la prensa de izquierda, que prefería enfocar su atención en las organizaciones que les resultaban más afines. Algo similar puede decirse sobre los gremios de los marineros, que se encontraban entre los más importantes del período, y que desde temprano se mostraron muy proclives a dialogar con las autoridades.

Que una asociación de trabajadores mereciera la atención de un jefe de Estado del siglo XIX estaba muy lejos de ser un fenómeno habitual. La dirigencia obrera finisecular solía entrar en contacto con las autoridades sólo con motivo de mítines y huelgas. Y si bien hubo ocasiones en las que el tratamiento de cuestiones vinculadas a la protesta popular convocó a actores políticos de primera línea (ministros y, en al menos una oportunidad, al presidente de la Nación) la protesta en la calle o el lugar de trabajo pertenecía al campo de cuestiones que competía a jefes policiales y municipales, los actores que construyeron los lazos más estrechos y duraderos con la dirigencia obrera. Pero al margen de los vínculos forjados en torno al conflicto y la movilización, es indudable que las 
características del sistema político no propiciaron la constitución de una relación de mayor densidad institucional entre las organizaciones de trabajadores y la élite gobernante (Hora, 2020).

¿De qué naturaleza era el impedimento? No se trataba de una objeción de principio. Desde que Hilda Sabato dio a conocer La política en las calles sabemos que los grupos gobernantes de la era liberal eran capaces de convivir con, e incluso promover, la manifestación popular (Sabato, 1998). Distintos trabajos muestran que la cultura de la movilización estuvo muy lejos de extinguirse en 1880; por el contrario, si algo sucedió en este plano, es que las movilizaciones se volvieron más frecuentes y concurridas (Sigal, 2006; Rojkind, 2006 y 2017). Al igual que otros actores, en repetidas ocasiones los trabajadores organizados ganaron la calle para dar testimonio de su presencia y hacer conocer sus reclamos. Del mismo modo, sabemos que algunas fracciones de la élite dirigente encontraron apoyos entre los asalariados cuando empujaron proyectos de mejora laboral. La mejor prueba de ello lo ofrece la manifestación en favor del proyecto de jornada de 8 horas promovido por un legislador del radicalismo porteño, Eduardo Pittaluga, en octubre de 1894. Desatendida en los estudios que conciben a la política obrera bajo el prisma del antagonismo y la formación de una cultura de clase, la importancia de este evento no debería subestimarse: fue la manifestación más numerosa de la historia del sindicalismo argentino decimonónico (Hora, 2020).

En efecto, el 14 de octubre de 1894, las principales organizaciones obreras de Buenos Aires y La Plata ganaron la calle para respaldar el proyecto de 8 horas del radical Pittaluga. En esa marcha tomaron parte asociaciones socialistas y anarquistas, junto a otras que no veían necesidad de pronunciarse sobre cuestiones referidas a orientación político-ideológica. Juan B. Justo acompañó las columnas obreras como un manifestante más, junto a varios estudiantes universitarios de simpatías socialistas. El hecho de que la vanguardia organizada de la clase obrera estuviese dispuesta a movilizarse para respaldar una iniciativa proveniente de un político «burgués» es un buen indicador del grado de flexibilidad político-ideológica que entonces predominaba en las filas proletarias. E invita a preguntarnos si, en caso de haber contado con mayores estímulos, ese sindicalismo podría haber tomado un camino afín al que marcó su trayectoria medio siglo más tarde, cuando fue convocado a sumarse a un programa político más vasto desde la Secretaría de Trabajo y Previsión. En todo caso, la respuesta positiva de muchos trabajadores ante una propuesta surgida del seno de la elite dirigente sirve para recordarnos que el hiato entre Estado y trabajadores organizados no debe entenderse, sin más, como el resultado de una supuesta impronta contestataria del naciente movimiento obrero. Más bien, este ejemplo sugiere que para entender los obstáculos que impidieron la emergencia de un gremialismo mejor integrado en las estructuras políticas de la república oligárquica -conviene señalar, siquiera al pasar, que este concepto merece una discusión más profunda, que cae fuera de los objetivos de este ensayo ${ }^{[6]}$ - también hay que mirar al otro lado de la cerca. Pues ningún sector de la dirigencia política apostó a incrementar su propia gravitación en la vida pública extendiéndole la mano a la dirigencia obrera, e invitándola a participar de un programa de incorporación o reforma laboral (Hora, 2020).

¿Por qué no hubo más Pittalugas en el seno de la élite dirigente? Un episodio de 1901 deja bien en claro que, incluso en los sectores más encumbrados de la clase 
gobernante, no existía una objeción de principio a reconocer la legitimidad de las demandas proletarias. El evento en cuestión es la manifestación de desocupados promovida por el Partido Socialista el 12 de agosto de 1901. Ese día, una importante columna, integrada por varios miles de trabajadores, marchó hacia la Plaza de Mayo. El objetivo de la movilización popular era entregarle a las autoridades un petitorio solicitando medidas para combatir el desempleo, en ascenso en esos meses. ¿Cuál fue la reacción del presidente Roca ante la presencia proletaria en la Plaza? El primer mandatario no sólo recibió en su despacho a la delegación socialista que había organizado la marcha. También la invitó a salir al balcón de la Casa Rosada desde donde el socialista Julio Arraga, y luego el propio Presidente de la Nación, les dirigieron la palabra a los trabajadores reunidos en la Plaza ${ }^{[7]}$.

Los relatos del evento sugieren que Roca se fastidió porque su discurso fue acompañado por algunos silbidos. No parecen haber sido tantos ni tan hirientes, sin embargo, como para interrumpir el discurso del presidente de la Nación. De hecho, la escena irritó más a los anarquistas que al propio Roca. Tanto es así que La Protesta Humana alzó la voz para criticar «la mansedumbre» de los manifestantes como «la desfachatez de los gobernantes, que desde los balcones, peroran a los descamisados como empedernidos demagogos» ${ }^{[8]}$. Descamisados que elevan su mirada hacia el balcón de la Casa Rosada, demagogos (la expresión «populistas» todavía no había ganado relieve) que peroran desde esos balcones... Sin embargo, aún si se lo hubiera propuesto, Roca no podía convertirse en un antecesor del Perón de octubre de 1945. Esas columnas obreras que se acercaban al poder haciendo uso de su derecho a peticionar, y en busca de reconocimiento y atención, eran demasiado exiguas como para que fuesen tomadas en serio por la elite gobernante. La debilidad de las asociaciones gremiales o de las fuerzas de izquierda, y su muy acotada capacidad para movilizar a los trabajadores, cuyas preferencias político-ideológicas tendían a orientarlos en otras direcciones (volveré sobre este punto más abajo) volvían poco prometedora cualquier empresa de seducción de esa naturaleza.

El hecho de que el sistema político no ofreciera incentivos suficientes como para incorporar masivamente a los asalariados urbanos (muchos de los cuales, además, eran extranjeros) a la disputa electoral constituía otro serio impedimento a toda iniciativa dirigida a transformar al gremialismo en un interlocutor regular del poder político. Aún en los momentos en los que la competencia política se tornó más abierta e inclusiva (la primera mitad de la década de 1890), cortejar a las modestas organizaciones gremiales de ese tiempo difícilmente pudiera ofrecer grandes dividendos políticos. Movilizar apoyos en el gremialismo tampoco parece haber estado dentro del horizonte mental de la dirigencia partidaria; la renuencia incluso de figuras como Pittaluga a explotar políticamente las simpatías que había concitado en el mundo gremial, o entre los trabajadores, es bien reveladora de esta inhibición. A todo ello se agrega que, por razones que en breve pasaremos a señalar, la mayor parte de los asalariados prefería jugar sus cartas mirando hacia el mercado antes que presionando sobre el Estado.

A fines del siglo XIX, pues, una organización proletaria que se hallaba poco integrada en las instituciones de la república capitalista, pero que admitía su legitimidad y se había acostumbrado a funcionar en su marco, era la corriente de mayor gravitación del emergente movimiento obrero. Algunas de estas 
organizaciones estaban lideradas por activistas inspirados en ideales socialistas o anarquistas, pero estas ideas no deben ser vistas como el único factor que determinaba su práctica sindical. De hecho, es muy dudoso que la mayor parte de los trabajadores se sintiera atraído por la política o la cultura de izquierda. Es lo que, muy a su pesar, reconocía el joven Bartolomé Bosio cuando advertía, desde las páginas de La Vanguardia, que la postura «apolítica» era la que mejor se adaptaba a la sensibilidad dominante entre los asalariados. Bosio denunciaba que «el corporativismo más puro» se estaba «arraigando en la clase obrera»y, en consecuencia, los trabajadores «se espantan» cuando percibían que sus organizaciones gremiales se subordinaban a fines políticos. La política, se lamentaba Bosio, «es el terror de los trabajadores», que preferían un sindicalismo eximido de todo compromiso político más amplio ${ }^{[9]}$. La debilidad de socialistas y anarquistas, podríamos agregar, solía acentuar este deseo de prescindencia. En efecto, ¿por qué seguir a dirigentes cuyo programa, en vez de contribuir a incrementar el poder de la organización obrera, corría el riesgo de debilitarlo? Llegado este punto, pues, conviene dejar de lado el mundo del gremialismo de izquierda para explorar otros factores que moldearon la relación política entre los trabajadores y la sociedad argentina.

\section{Mercado de trabajo, sociedad y organización gremial}

Más allá de la cuestión de la orientación ideológica de los activistas y las organizaciones obreras, la difusión de la prédica gremial encontraba una de sus principales limitaciones en las profundas transformaciones sociales que por entonces experimentaba esta república austral. Una de las expresiones de este fenómeno era el arribo, año a año, de gran número de trabajadores extranjeros. Recordemos que, en ese período, en la región pampeana y en particular en las grandes ciudades litorales, más de la mitad de los asalariados eran migrantes europeos. Estos trabajadores se abrían camino en un mercado de trabajo que, empujado por la expansión económica más importante de toda la historia nacional, pagaba altos salarios y ofrecía numerosas oportunidades para desplazarse hacia empleos mejor remunerados. Que la Argentina ofrecía remuneraciones elevadas era un dato que nadie desconocía. Lo vemos confirmado en textos tan emblemáticos como el manifiesto fundacional de La Vanguardia salido de la pluma de Juan B. Justo (aunque allí se alertaba, en línea con lo que sugiere el último capítulo del tomo I de El Capital, que, como no podía ser de otra manera, esos «salarios relativamente elevados» se debían a «circunstancias transitorias», que llegarían a su fin una vez constituido «el ejército de desocupados que ya tiene a su disposición la clase capitalista de los otros países más adelantados») $)^{[10]}$.

Sobre los trabajadores, y en particular sobre los extranjeros, también incidía, con igual o mayor fuerza, la aspiración a dejar atrás la condición proletaria, el deseo de ingresar en las filas de los sectores propietarios o, en su defecto, de acumular ahorros que luego serían volcados en proyectos de mejora personal o familiar en los lugares de los que habían partido, del otro lado del Atlántico. La elevada tasa de retorno (la más alta de los países de inmigración de ese tiempo) y la amplitud relativa del horizonte de mejora social hacían que, para muchos asalariados, pues, la condición proletaria fuese circunstancial. Aun si contaban 
con menos herramientas y enfrentaban más obstáculos para sacar provecho de las oportunidades que se abrían ante sus ojos, los trabajadores provenientes del interior del país que se acercaban a la región pampeana tampoco eran ajenos a las expectativas de mejora que suscitaba ese ciclo económico ascendente en un contexto de escasez de brazos y de trabajo calificado.

Por todos estos factores, esa sociedad magmática -que, mientras acrecentaba el prestigio y el poder de su élite, también expandía sus clases medias, y seducía a sus clases populares con un horizonte de mejora del ingreso y movilidad social-, dificultaba la forja de una sólida identidad de clase trabajadora y, en particular, obstaculizaba la constitución de identidades subalternas de impronta contestataria, anticapitalista. Esas razones también disminuían el atractivo de invertir energía en la acción colectiva proletaria. Por supuesto, la experiencia del progreso no alcanzaba a todos de la misma manera, pero sí era lo suficientemente extendida como para incidir sobre las visiones dominantes sobre lo que el país estaba en condiciones de ofrecer.

Por la naturaleza de su economía, por las características de su fuerza laboral, por las oportunidades que abría para la mejora personal, la Argentina del cambio de siglo premiaba el individualismo más que la solidaridad de clase. Tanto es así que, en contraste con la visión que todavía impera en algunos historiadores del trabajo de nuestro tiempo, que suelen enfatizar el vigor de las ideologías anticapitalistas, los propagandistas de la solidaridad proletaria sabían bien que, también en este plano, nadaban contra la corriente. Una nota aparecida en La Vanguardia a comienzos de 1902 describe bien el escenario en el que la izquierda política y sindical debía presentar batalla contra estos argumentos. Según el vocero socialista, los inmigrantes:

«llegan a un ambiente social donde nadie se conoce y donde todos tienen por objetivo lucrar, enriquecer pronto, hacer la América, para regresar al país natal. Todo esfuerzo que tienda a crear condiciones de bienestar colectivo parece retardar el bienestar individual; y cuando se habla de organización suele responderse: 'que cada cual se las arregle’. No extrañe que reine la apatía y la abstención» ${ }^{[11]}$.

Socialistas y anarquistas solían apelar a estos razonamientos -con frecuencia combinados con referencias a la ignorancia o la orfandad intelectual de las clases populares- cuando creían necesario justificar sus modestos logros organizativos. Pero los motivos evocados por La Vanguardia son mejores para dar cuenta de la renuencia de muchos trabajadores a congregarse en sociedades gremiales que para explicar por qué los que sí tenían vocación gregaria, que no eran pocos, no siempre vieron a las asociaciones de izquierda como su primera opción para canalizarla. De allí que una mejor comprensión del problema de los límites del asociacionismo proletario invita a situar la cuestión en el marco más general que nos ofrece el panorama asociativo de ese tiempo. Y al ampliar el foco de indagación advertimos que los inmigrantes tenían a su alcance otro mundo de sociabilidad, el del asociacionismo étnico, que en varios aspectos competía con ventaja con el organizado en torno a la idea de comunidad obrera o a razonamientos que pivoteaban en torno al concepto de interés de clase.

La potencia del asociacionismo étnico argentino es conocida. En efecto, por su alcance y envergadura, este emprendimiento fue «notable en comparación con cualquier otro contexto inmigratorio» (Devoto, 2003:246; también Moya, 2005). Las razones de su arraigo no son difíciles de establecer. La dictadura 
rosista hizo a la Argentina de la era liberal un latecomer también en el plano del desarrollo de instituciones de la sociedad civil, por lo que el asociacionismo étnico surgió en un territorio casi virgen, que le dio muchas oportunidades para crecer y prosperar. Acompañando el auge inmigratorio, el asociacionismo étnico nació para resolver problemas prácticos que iban desde enriquecer la vida social y encontrar pareja a conseguir empleo; por supuesto, también ayudaba a combatir la soledad y protegía contra la enfermedad. Finalmente, considerando los orígenes culturales de los migrantes, a muchos hombres y mujeres el asociacionismo étnico seguramente debió resultarles más familiar que el organizado en torno al mundo del trabajo o la idea de comunidad de los explotados.

Ya bien arraigado cuando la izquierda comenzó a caminar sus primeros pasos, el tejido asociativo étnico siempre atrajo a una parte considerable de los asalariados. En un estudio clásico, Gandolfo mostró que condición étnica y condición de clase no siempre se vinculaban de manera armoniosa en el seno de esas instituciones (Gandolfo, 1992). Al margen de estas tensiones, que no tienen nada de sorprendentes, muchos trabajadores encontraron allí apoyos sobre los que recostarse que, de manera directa o indirecta, pusieron límites a la expansión de la oferta política o sindical articulada en torno a principios clasistas. Lo mismo vale para la relación entre la poderosa prensa étnica y la gremial o política de izquierda. Diarios de gran tirada como La Patria degli Italiani o El Correo Español y luego El Diario Español-apenas un escalón por debajo de La Prensa y La Nación - también acotaron el alcance de los periódicos gremiales, La Protesta Humana o La Vanguardia.

Varios estudios exploraron el problema de la relación entre condición étnica y demandas proletarias desde el mirador que ofrecen las asociaciones étnicas ${ }^{[12]}$. Con su mirada puesta en los procesos de formación de una cultura y una política obreras, los historiadores del trabajo le han prestado menos atención. Sin embargo, no hace falta internarse demasiado en el universo gremial para advertir las perturbaciones que el asociacionismo étnico supuso para la constitución de un entramado institucional basado en la solidaridad de clase.

Un par de ejemplos sirven para ilustrar su significación. En 1895, cuando los animadores de la pequeña sociedad gremial de albañiles se propusieron ampliar su radio de acción rápidamente identificaron al asociacionismo étnico - con sus poderosas sociedades de socorros mutuos, con sus clubes y centros de sociabilidad-como su principal rival. Allí, decían estos activistas, se invertían los recursos, el tiempo y la lealtad de muchos asalariados que, antes o además de trabajadores, se reconocían como miembros de una colectividad inmigrante. En una nota publicada en La Unión Gremial interpelaron a sus colegas de faena con estas palabras: « ¿por qué no venís a asociaros a vuestros compañeros, que os esperan como a hermanos queridos o hijos pródigos? Vosotros preferís estar asociados en las grandes sociedades de Mutuo Socorro que tienen grandes palacios y salones decorados mientras vosotros que pagáis el lujo vivís en una miserable choza» ${ }^{[13]}$. Un quinquenio más tarde, Jacinto Oddone volvía a plantear la misma queja desde las páginas de La Vanguardia: «repetidamente hemos llamado la atención de los obreros acerca de la explotación de que son víctimas por parte de esos centros de patrioterismo llamadas sociedades italianas 
de socorros mutuos» que, para colmo, se lamentaba el socialista, para entonces avanzaban en la creación de una bolsa de trabajo ${ }^{[14]}$.

Hay que tener en cuenta que el atractivo del asociacionismo étnico no dependía exclusivamente de su capacidad para ofrecer sociabilidad y servicios que, buenos o malos, muchos inmigrantes solían requerir y apreciar. Ese proyecto también seducía porque estaba identificado con una idea de comunidad, la comunidad nacional, que no se esfumó cuando esos extranjeros pisaron tierra americana. Los socialistas denunciaron muchas veces el poder del sentimiento «patriotero» con el fin de justificar los modestos logros de su propaganda en favor de la adopción de la ciudadanía argentina ${ }^{[15]}$. La pervivencia de las identidades étnicas fue subrayada por Ricardo Falcón en un ensayo en el que sugirió que este fenómeno explica por qué los anarquistas, que rechazaban de plano el programa nacionalizador del Estado argentino, fueron más exitosos que los socialistas al momento de concitar la lealtad de los trabajadores (Falcón, 1987). Desde entonces, este argumento ha sido repetido muchas veces ${ }^{[16]}$. A los fines del problema que aquí nos interesa explorar, la observación de Falcón tiene un costado relevante que, bien mirado, no abona la conclusión a la que arribó el historiador rosarino. Pues cuando colocamos la cuestión nacional en una perspectiva más amplia -esto es, cuando dejamos de lado la premisa de que la izquierda era el único actor que debe ser tenido en cuenta al momento de aproximarnos a las ideas y la política popular- lo que salta a la luz es que, más que favorecer la difusión del ideario libertario, la vigencia de las identidades étnicas debe haber servido para acotarla. Y ello era así porque esas identidades étnicas se maridaban con una ideología muy arraigada y vigorosa como es el patriotismo, muy visible en las principales comunidades inmigrantes.

En el caso de los inmigrantes españoles, una buena prueba de la intensidad de esos sentimientos de afecto hacia la tierra de origen y las instituciones que allí imperaban nos la ofrecen las movilizaciones organizadas durante la guerra de Cuba y, con todavía mayor claridad, las que tuvieron lugar durante la visita de la Infanta Isabel de Borbón con motivo de los festejos del Centenario de la Revolución de Mayo. A su arribo a Buenos Aires, el 18 de mayo de 1910, la princesa de Asturias fue recibida por una enorme multitud, en la que por supuesto predominaban los peninsulares. Unos 200.000 manifestantes (casi el 20\% de la población de la ciudad, que era de 1,3 millón), muchos de los cuales eran trabajadores, participaron del acto. El hecho es relevante no sólo porque parece haber sido «la mayor movilización de gente que se había visto en Buenos Aires» hasta entonces (Devoto, 2005:179). Lo es también porque supuso un desafío abierto a la dirigencia anarquista, que había convocado, para ese mismo día, a una huelga general.

En lo que respecta a los italianos, la evidencia, además de contundente, nos permite tomarle el pulso a la relación entre la que entonces era la principal comunidad extranjera del país y los ideales libertarios justo en los años examinados en estas páginas. La prueba más palmaria de la vigencia y la intensidad del compromiso de los italianos con su nación lo ofrece la multitud que recorrió las calles de Buenos Aires (y también de otras ciudades del país) el 12 de agosto de 1900 para honrar la memoria del Rey Humberto I, ultimado pocos días antes, en Monza, por el anarquista Gaetano Bresci. El caso es interesante puesto que, tanto por el lado de la víctima como por el de su victimario, el episodio tocaba fibras 
políticas muy sensibles, centradas en la oposición entre monarquía y anarquismo. Por ello es muy revelador que los sucesos de Monza produjeran mucho más rechazo que adhesión.

En efecto, y aunque algo menos numerosa que las grandes procesiones realizadas en el exultante clima del Centenario, la enorme manifestación que rindió tributo al rey de Italia se ubicaba varios escalones por encima del umbral en el que se movía la izquierda política o gremial. Es muy dudoso que, hasta 1900, anarquistas o socialistas hubieran logrado sacar a la calle a la décima parte de las más de 100.000 personas que, en una ciudad que entonces contaba con unos 800.000 habitantes, homenajearon al monarca caído. Las nutridas columnas de italianos que llevaron luto por Humberto pusieron de relieve el carácter minoritario del arraigo socialista y sobre todo ácrata en la mayor comunidad obrera extranjera del país. Y no puede caber duda alguna sobre el hecho de que fueron muchos más los asalariados peninsulares que rindieron tributo a Humberto I que los que formaron fila del lado de su verdugo, o de los críticos de la monarquía. En el homenaje, nos recuerda Martín Albornoz, estuvieron presentes «de forma particularmente destacada por todos los medios de prensa... inmigrantes de los barrios proletarios» (Albornoz, 2015:91). Para esa inmensa masa de trabajadores, dentro de los cuales predominaban ampliamente los católicos, si había alguna ideología exótica o que merecía rechazo, es la que venía de la izquierda radical y, seguramente para no pocos de ellos también, de la izquierda a secas.

\section{Católicos y empresarios frente al problema obrero}

La identificación de parte considerable de los inmigrantes con el credo católico es importante para comprender la inquietud con que la izquierda asistió, en esos años, al desembarco de los agentes de la Iglesia de Roma en el mundo del trabajo. Este fenómeno aparece mencionado en distintos estudios que refieren cómo, a comienzos de la década de 1890, en el camino abierto por la encíclica Rerum Novarum (1891), el padre Federico Grote creó los primeros Círculos Católicos de Obreros (por ejemplo, Lobato, 2000). Pero la idea de que la odisea de los trabajadores debe ser encuadrada como una historia de formación de una cultura obrera de impronta contestataria ha dificultado la incorporación del gremialismo católico al panorama del mundo del trabajo finisecular. Empero, el catolicismo popular no fue un fenómeno irrelevante $y$, hasta cierto punto, el gremialismo cristiano tampoco lo fue. Al menos no lo fue para la izquierda, que en esos años siguió con preocupación la emergencia de este dinámico rival en la disputa por el alma proletaria. De hecho, los Círculos Obreros fundados por Grote pronto reunieron más seguidores que los centros socialistas o libertarios. Para comienzos de siglo, la existencia de unos cuarenta Círculos Católicos de Obreros que decían tener unos 10.000 afiliados nos ofrece una medida de la envergadura de este proyecto ${ }^{[17]}$. Conferencias y mítines y, sobre todo, procesiones en la vía pública, y hasta marchas a Plaza de Mayo, le dieron visibilidad a la irrupción de este catolicismo masculino y militante (Lida, 2018). El año 1900 fue, no por casualidad, el del lanzamiento de El Pueblo, el diario con el que el catolicismo aspiraba a llegar a un público de masas (Lida, 2012). Y aunque nunca pudo competir con la gran prensa, esta empresa pronto se reveló mucho más exitosa 
que El Diario del Pueblo, el matutino creado por los socialistas un año antes con idéntico fin (Buonuome, 2017).

En repetidas ocasiones, la izquierda alzó la voz contra el avance de este agresivo competidor. El periódico sindical La Unión Gremial empleó la portada de su primer número, aparecido en abril de 1895, para denunciar a Grote y su «majada» ${ }^{[18]}$. En años posteriores, las huestes del sacerdote redentorista siguieron conquistando terreno. «Mientras los católicos organizan círculos parroquiales, escuelas diurnas y nocturnas y tratan de abrir almacenes generales para sus afiliados, la Cooperativa Obrera de Consumo y la Escuela del Pueblo llevan vida raquítica», se quejaba uno de los editores de La Vanguardia en $1901^{[19]}$. Los anarquistas también dieron la voz de alarma. En su congreso fundacional, celebrado en 1902, la Federación Obrera libertaria se ocupó de señalar que «las sociedades católicas de obreros deben ser combatidas» ${ }^{[20]}$.

Pese a que tenían más de asociación mutual que de sindicato, a que su dirigencia no provenía del mundo obrero sino de esferas más encumbradas, y a que no contaron con el apoyo entusiasta de la jerarquía eclesiástica -recelosa de las posibles desviaciones plebeyas del obrerismo católico-, los Círculos tenían un programa social. A las distintas voces de la izquierda esa agenda podía resultar insuficiente o demasiado marcada por la idea de conciliación de clases, pero no por ello los historiadores debemos ignorarla. Medida con la misma vara que empleamos para aquilatar el peso de la izquierda política o gremial, la capacidad de movilización de este catolicismo obrero, e incluso su gravitación electoral, no parecen insignificantes. En esos años, la movilización católica en favor del descanso dominical fue más importante que la socialista, e incluyó marchas a la Casa Rosada como la de septiembre de $1901^{[21]}$. La elección nacional de 1904 no sólo debería recordarse porque, en parte gracias a los votos del Partido Republicano, Alfredo Palacios pudo franquear las puertas del Congreso Nacional. Junto con el primer diputado socialista de América también ingresó a la cámara baja Santiago O'Farrell, presidente y gran animador de los Círculos Católicos de Obreros. Y es importante reparar en que O’Farrell promovió, codo a codo con el diputado socialista por la Boca, leyes como la de descanso dominical (1905) y de reglamentación del trabajo de mujeres y menores (1907).

Aún nos falta entender mejor por qué el gremialismo católico no terminó de cuajar. A la luz de la escasa información disponible es posible aventurar que este proyecto fue visto con cierta desconfianza en el seno de la Iglesia pero, sobre todo, le faltaron los incentivos que le hubiera dado la existencia de una izquierda más vigorosa, o de una población trabajadora con una cultura de clase más arraigada. En un punto, pues, el gremialismo católico fue víctima de los mismos factores que limitaron el crecimiento de sus rivales ubicados en el otro extremo del campo político-ideológico. En ese espejo se reflejaron, invertidos, sus propias limitaciones. Su relativa debilidad, que se volvió evidente entrado el nuevo siglo, el ya mencionado énfasis de muchos estudios de historia popular en las organizaciones de izquierda, así como motivos de naturaleza más propiamente ideológica e historiográfica -asociados a la idea de que ese programa carecía de legitimidad política, que era puro «sindicalismo amarillo»- explican por qué los historiadores del trabajo le han prestado poca atención a este proyecto deslucido. Sin embargo, sería un error concluir que los trabajadores eran indiferentes al mensaje de la Iglesia. Observar el problema con una perspectiva temporal más 
extensa invita a concluir lo contrario. Las grandes movilizaciones populares del Congreso Eucarístico de 1916 y, sobre todo, del realizado en 1934, nos revelan el vigor del sentimiento popular cristiano. Y el hecho de que los motivos católicos ocuparan un lugar muy prominente en la ideología del sindicalismo peronista mucho más destacado que los asociados con la tradición laica y progresista, cuyo puntal nunca fue el trabajador raso sino el activista y el dirigente- sugiere que la unión de la cruz y el martillo no carecía de arraigo en el mundo obrero y, por tanto, de potencial político, y que la izquierda del cambio de siglo tenía buenos motivos para temer su activación.

El empresariado también debe ser tenido en cuenta en todo intento de recrear el ambiente en el que se movían las organizaciones de trabajadores. No tanto o no sólo porque, como era esperable, los patrones vieran con poco entusiasmo la formación de sindicatos obreros. Más importante es que también ellos realizaron esfuerzos para poner a los asalariados de su lado. No fueron pocos los capitalistas que apelaron a la movilización de los sentimientos nacionales y/o religiosos de sus empleados. El factor étnico fue un criterio habitual al momento de contratar trabajadores o de promoverlos a puestos de mayor responsabilidad ${ }^{[22]}$. Pero las organizaciones patronales incluso fueron más allá, invocando la idea de que trabajadores y empleadores tenían intereses coincidentes. No lucha sino colaboración de clases.

Los dueños de fábricas que requerían (o se beneficiaban de) protección aduanera eran el grupo mejor posicionado para invocar este principio. El proteccionismo manufacturero ofreció oportunidades para la conformación de alianzas entre empresarios y trabajadores a partir de argumentos tales como la necesidad de defender los puestos de trabajo y un determinado nivel de remuneraciones contra la amenaza que suponía la competencia de la producción importada. Considerando que la Buenos Aires de fin de siglo era el principal polo manufacturero de América Latina, y que esa industria había crecido a la sombra del proteccionismo aduanero, está claro que esas oportunidades no podían ser insignificantes. La manufactura gozaba de un nivel relativamente alto de protección que, lejos de estar aceptado y asegurado, concitaba la crítica de los partidarios de una economía más abierta, entre los que se contaban no sólo los socialistas sino también, y más importante, el empresariado rural. En este marco, el arreglo proteccionista creó un terreno de encuentro entre trabajadores y patrones industriales (Rocchi, 2006; Hora, 2009).

El programa proteccionista no se apoyó sólo en ideas o en el lobby parlamentario. También se hizo sentir en la calle. La movilización obrera más numerosa del siglo XIX, la del 26 de julio de 1899 fue promovida por la Unión Industrial Argentina en nombre de la defensa de la manufactura nacional. Ese día, más de 50.000 trabajadores -hombres, mujeres y niños- marcharon por las calles de la capital del país siguiendo a sus capataces y patrones, en un desfile que pasó por el Congreso y terminó frente a la Casa Rosada. Dos años antes de salir al balcón para dirigir la palabra a trabajadores y desocupados movilizados por el socialismo, Roca habló ante los trabajadores movilizados por los patrones de fábricas. Y así como el influjo del catolicismo sobre el mundo obrero no nació en 1945, tampoco la colaboración obrero-patronal construida en torno a la industria protegida tuvo que esperar a la llegada de Perón para ponerse en marcha. Aunque con mucho menos velamen, también ese barco realizó sus primeras navegaciones 
bastante antes de que el coronel de los trabajadores se ubicara en el puente de mando $^{[23]}$.

\section{Los guardianes del orden y la política obrera}

Este breve recorrido nos confirma que el universo de actores e ideas políticas que interpelaban a las clases populares en su condición de trabajadores era complejo y diverso. Allí se escuchaban las voces de los militantes anticapitalistas pero también de agitadores de otras familias ideológicas, que nos recuerdan que el paternalismo y la idea y la práctica de la colaboración de clase también contaban con cierta capacidad de seducción. Entre esos puntos extremos se ubicaba el sector mayoritario del gremialismo, cobijado por las banderas, más silenciosas y anodinas, del sindicalismo de negociación. Aunque tenuemente integrados a la vida política y en particular a la competencia partidaria, ese proyecto parecía confiado en que tenía un lugar en el seno de la república capitalista.

Ello puede comprobarse si desplazamos el foco de atención desde los actores y las ideas que daban forma a la política obrera hacia la manera en que los guardianes del orden reflexionaban sobre la vida asociativa de los trabajadores. En la década de 1890, la Policía de la Capital Federal creó una comisaría de investigaciones cuyos tentáculos comenzaron a auscultar, de manera más sistemática, el ambiente popular (Albornoz y Galeano, 2016). El deseo de ejercer un control más estricto de los grupos tenidos por peligrosos animaba ese proyecto. Sin embargo, en su lista de desafíos al orden los centros obreros y las agrupaciones de izquierda ocupaban un plano muy secundario. De hecho, la publicación a través de la cual la fuerza policial daba a conocer sus puntos de vista, la Revista de Policía, prestaba más atención a los robos y estafas, a los delitos de sangre y los juegos de azar clandestinos, que a los peligros que podía acarrear la acción obrera o la protesta social.

Incluso la cuestión de la regulación del derecho de reunión, muy debatido en el cambio de siglo, se enfocaba en otros actores. Los eventos que llevaron a la policía a reclamar restricciones a las manifestaciones en la calle «por motivos relacionados con la seguridad» estuvieron vinculados con el impacto local de la política internacional (movilizaciones durante la Guerra por la independencia de Cuba) o con la disputa partidaria (mítines radicales). Por supuesto, las protestas estudiantiles contra el proyecto de consolidación de la deuda pública, que conmovieron a la capital del país y llevaron a la declaración del estado de sitio en julio de 1901, fueron el mayor disparador de las preocupaciones policiales por el orden público (Rojkind, 2017). En contraste con estos focos de tensión, hasta los sucesos de noviembre de 1902 que culminaron en una importante huelga, la protesta obrera en Buenos Aires -que a lo largo del siglo XIX nunca dejó víctimas fatales, ni entre la policía ni entre los manifestantes- no fue percibida como un factor de perturbación real o potencial del orden público de gran relevancia ${ }^{[24]}$. Ello se comprueba al recordar que, refiriéndose a los tumultos del 3 de julio de 1901 (epicentro de las protestas contra el proyecto de unificación de la deuda pública), el roquista Tribuna declaró que «las manifestaciones que [en el pasado] han hecho los socialistas y los anarquistas, en las que tomaron parte obreros pero también elementos peligrosos, no pueden ni compararse con los manifestantes de 
ayer. En aquéllas se proclamó la revolución social y se gritó contra la propiedad, pero nunca se asaltó ni se saqueó la propiedad» ${ }^{[25]}$.

Esta manera de concebir a la izquierda -como una comunidad deslenguada pero inofensiva- estaba bien extendida. El modo en que la Revista de Policía evaluó el proyecto de expulsión de extranjeros que el senador Miguel Cané presentó en 1899 ofrece evidencias que apuntan en esta dirección. Como es sabido, esa iniciativa parlamentaria fue rechazada por el Senado sin mayor debate. Lo que importa destacar es que las autoridades policiales tampoco la creyeron oportuna. Tanto es así que el artículo de la Revista de Policía que abordó la cuestión la criticó de manera abierta, denunciando su carácter superfluo y anticonstitucional. José Luis Duffy, el autor de la impugnación, era un funcionario muy cercano al jefe de la repartición, Francisco Beazley. Es dudoso, por tanto, que su nota sólo reflejara una opinión personal.

Amén de señalar la pobre factura del proyecto, Duffy no veía necesidad alguna de sancionar una ley de expulsión por cuanto, decía, el país no tenía enemigos a la vista: «el socialismo no es una amenaza, ni siquiera una mera posibilidad»; para reprimir a los anarquistas que violaban la ley, bastaba con el Código Penal. El senador Cané, advertía el funcionario policial, «tiene una falsa idea sobre los límites del derecho de castigar» ${ }^{[26]}$. Duffy subrayaba que «la medida de expulsión aplicada tan solo a los extranjeros y el procedimiento por el cual ha optado el Dr. Cané para llevarla a la práctica implican la violación más claras del espíritu de la Constitución Nacional, como también de preceptos terminantes de la misma» ${ }^{[27]}$. Duffy seguía imaginando a la inmigración europea, más que como un problema, como un engranaje fundamental para el progreso nacional: no había mejor instrumento para domesticar el «desierto», al que seguía describiendo, en clave alberdiana, como «el cáncer de los países americanos». De allí que, para atraer talento y energía extranjeros en grandes cantidades, «la liberalidad de las instituciones» debía figurar «en primera línea» ${ }^{[28]}$.

Esta liberalidad reclamada por Duffy era algo más que un artificio retórico, al menos en distritos como la capital de la república. A los ojos de muchos contemporáneos, incluyendo a los de izquierda, las garantías que las instituciones del país ofrecían a la acción política, pese a todas sus limitaciones, tenían existencia real. Socialistas y libertarios no sólo se habían beneficiado con ella sino que, además, eran bien conscientes de la existencia de un Estado que no imponía grandes restricciones a su accionar. Y también tenían buenas razones para considerar que ese orden político era bastante más generoso en términos de garantías y derechos que la mayor parte de los Estados que reglaban la vida de las clases populares en Europa Continental. Para comprobarlo es bueno recordar cómo el encargado de la representación italiana en Buenos Aires, el príncipe Lorenzo di Cariati, se refería a la política del Estado argentino hacia los anarquistas que desembarcaban en Buenos Aires. La legación italiana solía expresar su malestar por la libertad de que gozaban propagandistas de la anarquía como Mattei y Malatesta. En 1898, Di Cariati se lamentaba de que «según las leyes vigentes en la República», los «simpatizantes de ideas exaltadas o asociados a círculos anarquistas» podían ingresar y moverse libremente, y que las presiones de las autoridades italianas para alterar ese estado de cosas no rendían fruto (Ostuni 1985:119). 
Los anarquistas no se tomaron muy en serio a Cané cuando en 1899 presentó su proyecto de ley de residencia. La Protesta Humana creía que el senador «perdía el tiempo miserablemente filosofando sobre la conveniencia de su proyecto de leyes antianarquistas» ${ }^{[29]}$. Por supuesto, este clima de relativa tolerancia hacia la prédica anarquista ayuda a entender por qué tantos libertarios europeos eligieron afincarse en Buenos Aires: además del vigor de su mercado de trabajo, la ciudad poseía una industria editorial y círculos culturales muy activos, donde los ácratas se movían con más libertad que sus homólogos en Madrid, Roma o Barcelona. La misma conclusión se alcanza cuando vemos que, aunque envuelta en una retórica entrenada en el arte de la denuncia y la injuria, las quejas de los propagandistas de la anarquía solían tener motivos nimios. Que un grupo de libertarios dedicado a la pegatina de carteles fuese demorado por la policía por algunas horas era, a falta de afrentas más sustantivas, motivo suficiente como para que L'Avvenire o El Rebelde iniciaran una campaña de denuncia de la violencia estatal $^{[30]}$.

Igualmente reveladora es la reacción de los anarquistas ante hechos de mayor trascendencia. Es lo que aconteció en agosto de 1902, cuando un choque entre obreros y propietarios de panaderías dio lugar a un confuso enfrentamiento que dejó un par de víctimas fatales. El juez a cargo de la investigación decidió allanar el centro gremial de los panaderos en busca de pruebas con las que aclarar los asesinatos. Los panaderos compartían su modesto local con otras 17 sociedades gremiales, todas ellas integrantes de la filo-anarquista Federación Obrera. Nunca hasta entonces un local sindical había sido allanado. La preocupación que causó este hecho inédito se extendió mucho más allá de las filas del gremialismo libertario. De hecho, tanto socialistas como anarquistas recurrieron a la misma expresión para describir el procedimiento encabezado por el juez Navarro: «un malón». La Protesta Humana denunció que, como consecuencia de «un atropello sin antecedentes en los anales de la arbitrariedad gubernamental», ya no tenían «nada que envidiar los trabajadores de la Argentina a los trabajadores europeos en cuanto a arbitrariedad» ${ }^{[31]}$. Por su parte, La Vanguardia se escandalizó porque los auxiliares de justicia, «imitando a la soldadesca europea vencedora en Pekín, se entregaron con un entusiasmo singular, a violentar los escritorios y bibliotecas» del centro gremial ${ }^{[32]}$.

Las diferencias de escala entre el daño que causó el allanamiento y el censo de mártires que por entonces dejaba la represión del Estado español o italiano o la violencia de las incursiones imperialistas en Oriente no podía escapársele a nadie: el «malón» del juez Navarro no produjo víctimas ni detenidos, y sus únicos caídos fueron una vasija de barro, y algunos cerrojos y candados. Sin embargo, si la izquierda formulaba el problema en términos tan dramáticos era porque el tema importaba, y mucho, por cuanto ponía en cuestión la idea que anarquistas y socialistas se habían hecho sobre cómo funcionaba el Estado argentino y qué tipo de derechos les asistían. Ello explica por qué el socialista Comité de Propaganda Gremial lo calificó como «una tropelía y un atentado tan salvaje como inusitado por parte de los que debieran velar y hacer cumplir las garantías y derechos que la Constitución y las leyes consagran», y decidió enviar una nota de queja al ministro del Interior ${ }^{[33]}$. La cuestión tuvo la envergadura suficiente como para dar lugar a un mitin de repudio que La Protesta Humana quería fuese «el más 
imponente de todos los que han tenido lugar en esta república» ${ }^{[34]}$. Allí tomaron la palabra oradores libertarios y socialistas, que denunciaron «los desmanes de un juez ensoberbecido o ignorante» ${ }^{[35]}$. La concurrencia fue muy numerosa: 30.000 personas según la estimación anarquista, 20.000 según la socialista, y unas 5.000 de acuerdo a los cálculos más realistas de la prensa comercial. En cualquier caso, las garantías constitucionales no eran un asunto trivial para la izquierda. Esos derechos liberales - de asociación, de expresión, de huelga- conformaban un piso de garantías que parecía asegurado y cuya puesta en cuestión, por tanto, suponía no sólo un retroceso sino también un escándalo.

Ese escándalo, sin embargo, no significa que socialistas o libertarios se colocaran en un rumbo de colisión con las instituciones de la república capitalista. Su actitud sugiere que deseaban más bien lo contrario. Sus palabras y acciones revelan irritación pero no el tipo de sentimientos de alienación que suelen predominar entre los actores que habían roto lazos con las instituciones políticas que los gobernaban, o con los principios sobre los que se apoyaba la discusión pública. Esto vale tanto para los socialistas como para los anarquistas. Y hay que notar que periódicos como La Nación y La Prensa presentaron un relato de los hechos que traslucía simpatía por el reclamo panadero, y hasta $L a$ Protesta Humana señaló «la mala impresión con que los diarios recibieron su allanamiento» ${ }^{[36]}$.

De hecho la queja anarquista, que varios medios de la «prensa burguesa» consideraban legítima, no tenía por blanco principal al Estado o al sistema de justicia sino a un juez en particular, al que acusaban de extralimitarse en sus atribuciones. Tanto es así que el aspecto más revelador del conflicto desatado por el allanamiento al gremio de panaderos fue que los jefes libertarios de la Federación Obrera decidieron solicitarle al expresidente Carlos Pellegrini que se hiciera vocero de su denuncia en el Congreso Nacional ${ }^{[37]}$.

¿Qué explica el acercamiento de los gremiales anarquistas a una de las figuras más notables de la élite política? Las imágenes de la Plaza de Mayo y la Casa Rosada el día de la asunción de Pellegrini como presidente, en agosto de 1890, dan testimonio de la popularidad de este dirigente autonomista. Además de un político popular, Pellegrini era un político opositor. De hecho, desde que la crisis política de julio de 1901 lo había enemistado con Roca, Pellegrini se había convertido en un abierto impugnador del gobierno nacional. También es importante recordar que el líder del autonomismo porteño no era, en principio, hostil a la organización sindical. Unos años más tarde, incluso, llegaría a argumentar en favor de que los trabajadores participaran de las ganancias de las empresas (Zimmermann, 1995:175-77).

Con todo, la idea de erigir a Pellegrini en abogado de la causa de los panaderos anarquistas era quizás demasiado osada, y en rigor terminó siendo descartada por los propios jefes de la Federación Obrera. Pero el hecho de que todavía en agosto de 1902 un personaje tan prominente de la elite dirigente fuese seriamente considerado por los libertarios -lo que nos sugiere que llamarlos enemigos del orden establecido es casi una licencia poética- como un posible tutor de los derechos de los trabajadores en el Parlamento resulta significativa ${ }^{[38]}$. Hay que agregar que la irritación que la propuesta anarquista suscitó en las filas socialistas sin duda estaba vinculada con el rechazo que les provocaban las ideas económicas 
de Pellegrini (en particular, su defensa del proteccionismo) pero, sobre todo, con el hecho de que el Gringo era una figura popular y, por tanto, un rival de nota (en la visión de Juan B. Justo, «el peor de los cabecillas que arruinan y deshonran al país» ${ }^{[39]}$.

Todo esto nos revela que no conviene tomarse demasiado en serio las voces que argumentan que el régimen oligárquico imponía duras restricciones a la acción de la izquierda política o gremial, o que sugieren que el movimiento obrero estaba forjando su identidad en oposición al orden establecido. Si contrastamos la experiencia argentina con la de los países de la Europa continental, el razonamiento opuesto parece más verosímil. Montjuic era parte de un universo político muy distinto, y no sólo porque estaba situado al otro lado del Atlántico. La Protesta Humana se quejaba con frecuencia de la violencia policial, de los impuestos que pesaban sobre el pueblo trabajador y, por supuesto, también de la explotación de clase. Pero reconocía que «pocas naciones tienen una constitución tan libre como la República Argentina» y les recordaba a sus lectores que «la Constitución garantiza la facultad de asociarse para los fines que se crean convenientes» ${ }^{[40]}$. Un estudio reciente nos recuerda el contraste entre el ideario del socialismo argentino y el de su inspirador germano, cuyo Programa de Erfurt tomaba un camino muy distinto en «cuestiones que tenían que ver específicamente con las libertades políticas inexistentes en Alemania, así como con las demandas de libertad de opinión y contra la censura», ninguna de las cuales preocupaba demasiado en estas tierras (Poy, 2020:73).

Una formulación muy explícita de la relevancia de esa «liberalidad de las instituciones» celebrada por Duffy nos la ofrece Julio Arraga. En vísperas de las elecciones de septiembre de 1901, este dirigente socialista -a quien ya hemos encontrado, unos meses antes de esos comicios, acompañando a Roca en el balcón de la Casa Rosada- publicó un artículo en La Vanguardia donde se refería a las características del orden político en el que su partido debía desenvolverse. Según Arraga, al trabajador:

«Las leyes le garantizan el derecho de reunión, el de emitir sus ideas por medio de la prensa y sobre todo por el sufragio universal que pone en manos del obrero un arma poderosa, que manejada con inteligencia y perseverancia le asegurará su emancipación en un tiempo más próximo de lo que se piensa comúnmente. En otros países los trabajadores tienen que sostener cruentas y tenaces luchas para reclamar esas leyes liberales de que disfrutamos aquí: tenemos adelantado ese camino. Es cierto que las costumbres políticas son bárbaras todavía al pretender resolver las cuestiones electorales por el fraude y la revuelta; pero esas dificultades ... desaparecerán del comicio cuando los trabajadores conscientes y organizados se presenten en aquellos a ejercer sus derechos políticos» ${ }^{[41]}$.

Más que en la élite gobernante o en el sistema político, sostenía Arraga, el mayor obstáculo para el avance socialista eran las «bárbaras» costumbres del pueblo elector, al que era preciso elevar culturalmente y dotar de una nueva conciencia política. Muchas veces la izquierda -ácratas y socialistas por igualdescribió el problema político nacional en estos términos. Por supuesto, estos actores solían denunciar las miserias y egoísmos de las elites gobernantes, y el sesgo de clase que imprimían al gobierno. Pero en ocasiones también eran capaces de reconocerle algunas virtudes, así fuese de manera implícita. Así, por ejemplo, cuando el asesinato del presidente estadounidense William McKinley 
por un anarquista en septiembre de 1901 puso sobre el tapete la discusión sobre la conveniencia de restringir el derecho de admisión y permanencia de los extranjeros en el territorio nacional, el socialista Nicolás Repetto no creyó cometer ninguna falta al afirmar que confiaba en que, en la República Argentina, «el acendrado apego a las formas constitucionales impedirá o retardará la consumación del mayor de los disparates ${ }^{[42]}$. Y hay que señalar que, en esa ocasión, no se equivocó.

\section{Trabajadores, socialismo y liberalismo}

Prestar atención a los aspectos liberales de la vida pública es importante para comprender mejor las razones del poder integrador de esta república austral. Su promesa de inclusión se apoyaba ante todo en el plano socioeconómico, pero también poseía dimensiones específicamente políticas (Hora, 2020). Subrayar la importancia de esta cuestión permite situar mejor el que fue, quizás, el principal dilema práctico que el socialismo enfrentó en el cambio de siglo: cómo situarse frente a la agenda liberal. Varios estudios han señalado la importancia del liberalismo popular en la política latinoamericana decimonónica; en Argentina, en cambio, la premisa de que los trabajadores urbanos alcanzaron una temprana madurez ideológico-política (es decir, que avanzaron por la ruta del clasismo) ha puesto a la izquierda en el centro de la atención. Enfocados en la puja entre socialdemócratas y anarquistas y entre dirigentes partidarios y organizadores sindicales, los historiadores de la izquierda y el movimiento obrero no siempre han advertido que este sector de la opinión formaba parte de un campo de discusiones más amplio, que poseía numerosas conexiones con las posturas republicanas y liberales ${ }^{[43]}$.

En el cambio de siglo, la cuestión liberal ganó la atención de la izquierda como consecuencia de las reacciones que suscitó el ascenso del catolicismo político. La creación de los Círculos Católicos de Obreros, la formación de una Liga Demócrata Cristiana, el lanzamiento de un diario como El Pueblo (concebido no para la elite católica sino para el lector popular), mostraron que el catolicismo estaba en movimiento. Además de exhibir una importante capacidad de movilización, los católicos se anotaron importantes victorias, como el rechazo del proyecto de ley de divorcio de 1901. La activación de los católicos irritó a socialistas y anarquistas, pero también inquietó a muchos liberales. Y los liberales, todo sugiere, eran tantos o más que los socialistas o los anarquistas. Estudiantes y profesionales, pero también trabajadores y hombres del común, llenaron salones de conferencias y ganaron la calle para combatir, en nombre de los principios liberales, el avance del clericalismo. Crecida sobre el suelo anticlerical del que se nutría la cultura política porteña, la agitación liberal se reveló capaz de movilizar a varios miles de personas.

La activación de un liberalismo con tintes democráticos y populares supuso un desafío para la izquierda cuando Cosme Mariño, una de sus figuras más emblemáticas -impulsor, en 1899, del Partido Liberal-, llamó a formar el Centro de Obreros Liberales. Por un momento, incluso, esos centros atrajeron más atención que las agrupaciones socialistas o anarquistas. Quienes piensan que las ideas liberales y republicanas no tenían arraigo popular en el cambio de siglo harían bien en notar la conformación, por ejemplo, de un «Grupo Liberal 
de Obreros» entre los constructores de Carruajes y Carros, o la naturaleza de la resistencia a instrumentos de control laboral como la libreta de trabajo, condenada por la federación de conductores de vehículos como «una traba a la libertad del trabajo» ${ }^{[44]}$. Es más: las conferencias anticlericales promovidas por los trabajadores liberales concitaron, de acuerdo a La Vanguardia, una «enorme concurrencia» ${ }^{[45]}$. En estas circunstancias, no extraña que algunos socialistas se vieran tentados a explotar el potencial político de la agitación liberal.

Alfredo Palacios encabezaba ese pelotón. Próximo a Mariño, este joven abogado que se proclamaba socialista pronto se consagró como el más popular de los oradores anticlericales. Tan osado como ambicioso, Palacios se identificó con la causa liberal, a la que vio como una plataforma más apropiada que la socialista para desplegar una política progresista. A lo largo de 1901, Palacios que, por cierto, había ingresado a la vida pública unos años antes como orador católico, bajo los auspicios del padre Grote- habló con gran éxito en varios mítines liberales ${ }^{[46]}$. La actitud de Palacios causó escozor en el seno del Partido Socialista. Ni siquiera luego de afiliarse a esta agrupación, en el mes de septiembre de 1901, cejó Palacios en su apología explícita y enfática de la opción liberal. En un contexto político dominado por la cuestión clerical, sostenía Palacios, la causa liberal tenía mayor eco que la socialista. Agitar los temas de la agenda liberal -la separación de la Iglesia y el Estado, la denuncia de los privilegios y abusos del clero, el derecho al divorcio, etc.- era el mejor camino para conquistar a los trabajadores para una política progresista.

En noviembre de 1901, Palacios publicó un artículo en La Vanguardia exponiendo sus argumentos. Allí advertía que, mientras «el movimiento socialista ha marchado paulatinamente», el influjo de la Iglesia entre los trabajadores se expandía como una mancha de aceite, a punto tal que ya existía una gran «falange de proletarios a quienes los clericales o sus Círculos Católicos les proporcionan el socorro mutuo». Palacios quería contrarrestar el veloz avance de sus rivales mediante la formación de círculos liberales que promovieran «el socorro mutuo y otras ventajas que presentan los católicos»; ese era, sostenía, el mejor camino para «desprender de los tentáculos del pulpo clerical a esa falange de desgraciados que a cambio de médico a domicilio, botica y abogado gratis han abdicado de su independencia.» Una vez consolidados los círculos liberales, concluía Palacios, se abriría el capítulo de la política socialista: «el Círculo de Obreros Liberales comenzará la obra, los Círculos Socialistas la completarán ${ }^{[47]}$.

Aunque se declaraba «socialista convencido», Palacios abogaba por una estrategia política que, en la práctica, tenía poco de socialista ${ }^{[48]}$. De allí que recibiera duras críticas de las figuras más influyentes del partido, y entre ellos de Juan B. Justo, quien rechazó la idea de que los trabajadores argentinos necesitaran pasar por la estación liberal para arribar a la socialista ${ }^{[49]}$. Pero el hecho de que Palacios se mantuviera firme en su apuesta liberal era algo más que el producto de su egocentrismo. Sugiere que contaba con aliados dentro del partido -entre los que estaba, en primer lugar, el grupo de La Plata liderado por Alfredo Torcelli, donde había firmado su ficha de afiliación-y, más importante, que su visión tenía eco más allá de las escuálidas filas socialistas. El hecho de que en ninguna de las elecciones nacionales realizadas hasta entonces el socialismo pudiera presentar candidatos fuera de la Capital Federal -donde participaba desde 1896, y donde 
sus mejores cosechas no superaban los 200 votos- daba fuerza adicional a su disidencia.

A mediados de 1902, Palacios otra vez recurrió a las páginas de La Vanguardia para reafirmar sus argumentos: «sostuve y sostengo que los círculos liberales de obreros son organizaciones de circunstancias que se adaptan perfectamente al ambiente de nuestra sociedad» ${ }^{[50]}$. Y en noviembre seguía avanzando por esa senda: el primer día de ese mes La Prensa informaba que el joven abogado había sido ungido presidente del Centro Liberal de estudiantes de la Universidad de Buenos Aires ${ }^{[51]}$. Anticlericalismo, libertad, Estado laico: esas eran las banderas que, cuando 1902 estaba próximo a cerrarse, el joven Palacios quería alzar.

\section{Conclusiones}

Reparemos en la fecha en que el más popular orador de izquierda de ese tiempo reafirmaba su compromiso liberal con la juventud universitaria: noviembre de 1902. El dato es relevante porque en esos días ya estaba cobrando forma la protesta de los obreros del puerto que, aun si estuvo lejos de culminar en una auténtica huelga general (afectó a un número considerable de actividades en la ciudad de Buenos Aires, pero no tuvo mayor eco fuera de los confines de esta urbe, ni paralizó a todos los gremios) de todos modos imprimiría un giro de magnitud en la relación entre el Estado, la izquierda y las organizaciones de trabajadores. Apenas tres semanas antes de la sanción de la Ley de Residencia (debatida y aprobada el día 22) y de la airada reacción que la aprobación de esta norma anticonstitucional suscitó entre las clases trabajadoras, el joven cuya elección al Parlamento un año y medio más tarde, en marzo de 1904, lo transformaría en el primer diputado socialista de América Latina todavía desafiaba al círculo dirigente del partido Socialista con el argumento de que la bandera de la libertad era, desde el punto de vista político, más convocante que la insignia roja de la lucha de clases y la solidaridad obrera.

¿Se equivocaba Palacios? ¿Tenía una pobre comprensión del escenario en que se proponía desplegar el proyecto político progresista al que se mostró fiel por más de medio siglo? ¿Había elegido mal la estrategia con la que se proponía interpelar a las mayorías? Este artículo sugiere que no conviene apurarse a responder de manera afirmativa a estas preguntas. El hecho de que, todavía a fines de 1902, la figura más popular de la izquierda siguiera apostando por el camino liberal debería hacernos repensar la manera en que los contemporáneos concebían la escena política y esto, a su vez, nos obliga a reconsiderar las premisas que dominan las interpretaciones forjadas por los historiadores que se han ocupado de estos temas. La evidencia presentada en estas páginas pone de relieve que la política popular de las últimas décadas del siglo no debe narrarse concentrando la mirada, de manera privilegiada, en los avatares del ascenso de la izquierda y de la formación de una cultura obrera de rasgos anticapitalistas, de los que los progresos del anarquismo y el socialismo serían expresiones características. Más bien, invita a colocar el estudio de este sector de la opinión popular en un cuadro más amplio que, además de las agrupaciones «burguesas» que ocupaban el centro del escenario político y concitaban importantes adhesiones en el pueblo trabajador, también debe incluir otros actores: los católicos, los empresarios y los 
liberales y, por supuesto, las distintas vertientes de un gremialismo cuyo proyecto de poder estaba enfocado en el lugar de trabajo.

La evidencia presentada en este ensayo nos confirma el elevado grado de integración de las clases trabajadoras en el orden sociopolítico oligárquico. ¿Los sucesos de noviembre de 1902 introdujeron una inflexión en este cuadro? La respuesta no admite dudas: con la sanción de la Ley de Residencia comenzó un nuevo capítulo de la historia de la política popular, mucho menos consensual y pacífico que el analizado en estas páginas. Para abordarlo, sin embargo, es preciso despojarse del lastre que suponen las interpretaciones que conciben a esa crisis como un mero resultado del ascenso sociocultural del mundo proletario y la construcción de una cultura obrera de acusada impronta anticapitalista. Este punto de partida es fundamental para situar mejor la naturaleza de los conflictos que dominaron el período, más áspero y violento, que se extendió hasta el Centenario. Y, en términos más amplios, para comprender mejor las razones que explican las dificultades de nuestra izquierda política y gremial para ganarse un lugar de relieve a lo largo del siglo XX.

\section{Referencias}

ALBORNOZ, MARTÍN (2015): Figuraciones del anarquismo: El anarquismo y sus representaciones culturales en Buenos Aires (1890-1905). Tesis doctoral inédita, Universidad de Buenos Aires.

ALBORNOZ, MARTIN; BUONUOME, JUAN (2019): «La vida al día: modernización periodística y noticias policiales en la prensa anarquista y socialista de Buenos Aires a comienzos del siglo XX», en Investigaciones y Ensayos, (68), $81-122$.

ALBORNOZ, MARTÍN; GALEANO, DIEGO (2016): «El momento Beastly: la policía de Buenos Aires y la expulsión de extranjeros (1896-1904)», en Astrolabio, 7, pp. 6-41.

ALONSO, PAULA (2017): «Los partidos políticos y la nueva historia política de la Argentina del orden conservador. Entre la reflexión y el manifiesto», en Investigaciones y ensayos, 65 (2017), pp. 159-178.

BARRANCOS, DORA (2008): Mujeres, entre la casay la plaza. Buenos Aires: Editorial Sudamericana, 2008.

BUONUOME, JUAN (2017): «Los socialistas argentinos ante la . El semanario La Vanguardia y la modernización periodística en la Buenos Aires de entresiglos», en Boletin del Instituto de Historia Argentina y Americana Dr. Emilio Ravignani, 46.

BUONUOME, JUAN (2017): «Periodismo y militancia socialista en Buenos Aires a fines del siglo XIX», en Izquierdas, № 37.

CUCCHI, LAURA; ROJKIND, INÉS (2017): «Dossier - Oligarquía, República y Democracia: debates sobre la vida política en la Argentina del Orden Conservador», en Investigaciones y ensayos, 65, pp. 29-178.

DEVOTO, FERNANDO (2003): Historia de la inmigración en la Argentina, Buenos Aires: Sudamericana.

DEVOTO, FERNANDO (2005): «Imágenes del Centenario de 1910: nacionalismo y república», en JOSÉ NUN (comp.), Debates de Mayo. Nación, cultura y politica, Buenos Aires: Gedisa. 
DEVOTO, FERNANDO (2006): Historia de los italianos en la Argentina. Temas, Buenos Aires, Biblos.

DI MEGLIO, GABRIEL; FRADKIN, RAÚL; THUL, FLORENCIA (2019): $\ll_{i H u e l g a s}$ antes de los sindicatos? Notas para una historia larga de las luchas de los trabajadores en Argentina y Uruguay», en Archivos de historia del movimiento obrero y la Izquierda, (14), 11-31. https://doi.org/10.46688/ahmoi.n14.64

FALCÓN, RICARDO (1986-7): «Izquierdas, régimen político, cuestión étnica y cuestión social en Argentina (1890-1912)», en Anuario, Escuela de Historia, Universidad Nacional de Rosario, segunda época, 12.

FALCÓN, RICARDO (1986): El mundo del trabajo urbano, 1890-1914, Buenos Aires: CEAL.

GANDOLFO, ROMOLO (1992): «Las sociedades italianas de socorros mutuos de Buenos Aires: cuestiones de clase y etnia dentro de una comunidad de inmigrantes (1880-1920)», en DEVOTO, Fernando; MIGUEZ, EDUARDO (comp.), Asociacionismo, trabajo e identidad étnica. Los italianos en América latina en una perspectiva comparada. Buenos Aires: CEMLA-CSERIEHS.

GARCÍA COSTA, VÍCTOR (1997): Alfredo Palacios. Entre el clavel y la espada, Buenos Aires: Planeta.

HORA, ROY (2009): «La política económica del proteccionismo en la Argentina, 1870-1914», en Investigaciones y Ensayos, 58.

HORA, ROY (2019): «Izquierda y clases populares en Argentina, 1880-1945», en Prismas. Revista de historia intelectual, 23.

HORA, ROY (2020): «Trabajadores, protesta obrera y orden oligárquico. Argentina: 1880-1900», en Desarrollo Económico. Revista de Ciencias Sociales, 59:229.

LIDA, MIRANDA (2012): La rotativa de Dios: Prensa católica y sociedad en Buenos Aires: El Pueblo, 1900-1960. Buenos Aires: Biblos.

LIDA, MIRANDA (2018): «La caja de Pandora del catolicismo social: una historia inacabada», en Archivos de la historia del movimiento obrero y la izquierda, VII, 13.

LOBATO, MIRTA ZAIDA (2000): «Los trabajadores en la era del », en MIRTA LOBATO (ed.), El progreso, la modernización y sus limites (1880-1916), Buenos Aires: Editorial Sudamericana.

MIGUEZ, EDUARDO (2012): «Gestación, auge y crisis del orden político oligárquico en la Argentina. Balance de la historiografía reciente», en Polhis, 5:9. Disponible en: http://www.historiapolitica.com/datos/boletin/Polhis9_MIGUEZ.pdf

MOYA, JOSÉ (2005): «Immigrants and Associations: A Global and Historical Perspective», en Journal of Ethnic and Migration Studies, 31:5.

OSTUNI, MARIA ROSARIA (1985): «Inmigración política italiana y movimiento obrero argentino. Un estudio a través de los documentos gubernamentales italianos (1879-1902)», en DEVOTO, Fernando; ROSOLI, Gianfausto (comp.), La inmigración italiana en la Argentina, Buenos Aires, Biblos.

POY, LUCAS (2014): Los orígenes de la clase obrera argentina. Huelgas, sociedades de resistencia y militancia política en Buenos Aires, 1888-1896. Buenos Aires: Imago Mundi.

POY, LUCAS (2017): «El Partido Socialista y su delimitación con el movimiento anticlerical en los primeros años del siglo XX», en Anuario del Instituto de Historia Argentina, 17 (1).

POY, LUCAS (2020): El Partido Socialista argentino, 1986-1912. Una historia socialy politica, Santiago de Chile, Ariadna Ediciones. 
ROCCHI, FERNANDO (2006): Chimneys in the Desert. Industrialization in Argentina during the export boom years, 1870-1930. Stanford: California, Stanford University Press.

ROJKIND, INÉS (2006): «Prensa, manifestaciones y oposición política. La protesta contra la unificación de la deuda en julio de $1901 »$, en Estudios Sociales, 31.

ROJKIND, INÉS (2008-2009): «Visibilidad de la protesta social en Buenos Aires del novecientos», en Travesía, 10-11.

ROJKIND, INÉS (2017): «Campañas periodísticas, movilizaciones callejeras y críticas al gobierno. La participación política en el orden conservador», en Investigaciones y ensayos, 65, pp. 29-34. Disponible en: http://163.10.30.53/ojs_viejo/index.ph p/iye/issue/view/IyE_N_65

SABATO, HILDA (1998): La politica en las calles: entre el voto y la movilización. Buenos Aires, 1862-1880. Buenos Aires: Sudamericana.

SIGAL, SILVIA (2006): La Plaza de Mayo. Una crónica, Buenos Aires: Siglo XXI.

ZIMMERMANN, EDUARDO (1995): Los liberales reformistas. La cuestión social en la Argentina, 1890-1916, Buenos Aires: Editorial Sudamericana/Universidad de San Andrés.

\section{Notas}

[1] Ejemplos de esta visión en Falcón (1986), Lobato (2000) y Poy (2014). Para una contribución reciente que sitúa las transformaciones del fin de siglo en una perspectiva de largo plazo afín a esta perspectiva, Di Meglio, Fradkin y Thul (2019).

[2]Para una crítica más detallada, Hora (2019 y 2020).

[3]Para una aproximación a este problema, véanse los trabajos reunidos en Cucchi y Rojkind (2017).

[4] La cantidad de afiliados a la Federación Obrera, en La Protesta Humana, 26/04/1902. Los demás datos, Segundo Censo Nacional, Tomo II, pp. 47-50.

[5] Sobre la prensa de izquierda, Buonuome (2017) y Albornoz y Buonuome (2019).

[6] Para una discusión reciente, véase Miguez (2012), Alonso (2017) y Cucchi y Rojkind (2017).

[7] La Prensa, 13/08/1901. Una descripción del suceso en Rojkind (2008-2009).

[8]La Protesta Humana, 17/8/1901.

[9]La Vanguardia, 13/6/1903 y 20/6/1903. Un tiempo más tarde, Bosio terminaría sacando las conclusiones políticas que se derivaban de sus argumentos: abandonó el socialismo para sumarse a la corriente sindicalista.

[10] La Vanguardia, 7/4/1894.

[11] «Organización gremial», La Vanguardia, 18/1/1902.

[12]Para una síntesis, Devoto (2003).

[13] J. P. «A los albañiles», La Unión Gremial, 2, 18/4/1895.

[14] Jacinto Oddone, «Una nueva explotación», La Vanguardia, 14/9/1901.

[15] Por ejemplo, La Vanguardia, 10/1/1903.

[16]Véase, por ejemplo, Barrancos (2008:59-60). 
[17] La cifra en García Costa $(1997,89)$.

[18]La Unión Gremial, 4/4/1895.

[19] Guido Anatolio Cartei, «Anticlericalismo utópico y anticlericalismo científico», La Vanguardia, 21/9/1901.

[20] La Protesta Humana, 24/5/1902.

[21] «La policía y los desórdenes del domingo», Revista de Policía, V:105, 1 octubre de 1901, p. 140.

[22] Varios ejemplos en Devoto (2006:190).

[23]Para un mayor desarrollo, véase Rocchi (2006), Rojkind (2008-2009) y Hora (2009 y 2020).

[24] Revista de Policia, V:106, 16 octubre 1901, 148-9. Véase también Sigal (2006, 175).

[25] Tribuna, 4/07/1901, citado en Rokjind (2006:151).

[26] Revista de Policía, III:51, 1 julio 1899, pp. 35.

[27] Revista de Policia, III:52, 16 julio 1899, 53.

[28] Revista de Policia, III:51, 1 julio 1899, 38.

[29] Rictus, «Proyectos, proyectos!», La Protesta Humana, 20/9/1902.

[30] El Rebelde, 30/7/1899.

[31] La Protesta Humana, 16/8/1902.

[32] La Vanguardia, 16/8/1902.

[33] La Organización, número 20, septiembre de 1902.

[34] La Protesta Humana, 16/8/1902.

[35] La Vanguardia, 16/8/1902.

[36] La Protesta Humana, 16/8/1902. También La Nación del 8/8/1902 sobre el allanamiento, y el 17/8/1902 sobre el mitín.

[37] La Vanguardia, 16/8/1902.

[38] La Organización, número 20, septiembre de 1902.

[39] La Vanguardia, 29/3/1902.

[40] La Protesta Humana, 16/8/1902 y 5/4/1902.

[41] Julio Arraga, «A inscribirse», La Vanguardia, 14/9/1901.

[42] Publisher (Nicolás Repetto), «Los anarquistas del gobierno», La Vanguardia, 21/9/1901.

[43] En este punto, Poy (2017) constituye una excepción. Este autor analiza las consecuencias de la agitación anticlerical en la disputa de poder al interior del Partido Socialista, así como sobre las orientaciones ideológicas de esta agrupación.

[44] La Prensa, 4/11/1902.

[45] La Vanguardia, 22/6/1901.

[46] La Vanguardia, 12/10/1901.

[47] Alfredo L. Palacios, «Socialismo y liberalismo», La Vanguardia, 23/11/1901. 
Roy Hora. Socialistas, anarquistas, católicos y liberales: trabajadores y politica en la Buenos Aires del novecientos

[48] Ibid.

[49] Juan B. Justo, «Socialismo y liberalismo», La Vanguardia, 9/11/1901.

[50] La Vanguardia, 5/7/1902.

[51] La Prensa, 1/11/1902. 